\title{
HUBUNGAN RADIASI GELOMBANG ELEKTROMAGNETIK TELEPON SELULER TERHADAP FUNGSI PENDENGARAN MAHASISWA ANGKATAN 2009 FAKULTAS KEDOKTERAN UNIVERSITAS SAM RATULANGI MANADO
}

\author{
${ }^{1}$ Rut O. Battung \\ ${ }^{2}$ Jimmy F. Rumampuk \\ ${ }^{2}$ Wenny Supit \\ ${ }^{1}$ Kandidat Skripsi Fakultas Kedokteran Universitas Sam Ratulangi Manado \\ ${ }^{2}$ Bagian Fisika Fakultas Kedokteran Universitas Sam Ratulangi Manado \\ Email: rutoctovina@ymail.com
}

\begin{abstract}
Cell phone or usually called as mobile phone is one of the communication device that nowadays being developed. Global debate and controversy about the health effects of mobile phone keep continuing. There are some concerns about radio frequency energy (radio waves) emitted from the phone that may cause health problems, especially for auditory function. The observational analytic research with cross-sectional design has been carried out in NovemberDecember 2012. A number of 40 people have been chosen based on some inclusion criterias. The characteristics of the subjects were obtained by using a questionnaire and electromagnetic radiation examination of cell phones using electromagnetic field tester. Some auditory function tests were done using an audiometric. The data has been analyzed using Statistical Program Product and Service Solution (SPSS) with bivariate test (Pearson correlation). Audiometric tests showed there were eight students (20\%) with a mild hearing loss in the left ear and the rest 32 students (80\%) did not have a hearing loss. Meanwhile, three students (7.5\%) have a mild hearing loss in the right ear and the rest 37 students (92.5\%) did not have a hearing loss. Based on these results, it could be concluded that there was no significant relationship between electromagnetic wave radiation of cell phones and hearing function.
\end{abstract}

Keywords: cell phone radiation of electromagnetic waves, the function of hearing

Abstrak: Telepon selular atau biasa juga disebut handphone adalah salah satu alat komunikasi yang sedang berkembang saat ini. Perdebatan dan kontroversi secara global mengenai efek kesehatan dari telepon seluler terus berlanjut. Ada kekhawatiran bahwa energi frekuensi radio (gelombang radio) yang dipancarkan dapat menyebabkan masalah kesehatan, terutama terhadap fungsi pendengaran. Penelitian ini menggunakan metode analitik observasional dengan cara potong lintang (cross sectional), yang dilaksanakan pada bulan November-Desember 2012. Populasi sebanyak 40 orang yang tepilih sesuai kriteria inklusi, karakteristik subjek diperoleh melalui pengisian kuesioner, dan pemeriksaan radiasi elektromagnetik telepon seluler yang menggunakan Electromagnetic Field Tester serta pemeriksaan fungsi pendengaran yang menggunakan Audiometri. Analisis data dengan Statistical Program Product and Service Solution (SPSS) dan menggunakan uji bivariat (Pearson correlation). Hasil penelitian dengan audiometri menunjukkan mahasiswa yang mengalami gangguan pendengaran ringan pada telinga kiri sebanyak delapan orang (20\%) dan sisanya yaitu 32 orang (80\%) tidak mengalami gangguan pendengaran. Sedangkan, mahasiswa yang mengalami gangguan pendengaran ringan pada telinga kanan sebanyak tiga orang (7.5\%) sedangkan sisanya yaitu 37 orang (92.5\%) tidak mengalami gangguan pendengaran. Berdasarkan hasil penelitian dapat disimpulkan, tidak ada hubungan bermakna antara radiasi gelombang elektromagnetik telepon seluler terhadap fungsi pendengaran.

Kata kunci: radiasi gelombang elektromagnetik telepon seluler, fungsi pendengaran 
Telepon selular atau disebut handphone adalah salah satu alat komunikasi yang sedang berkembang saat ini. Peningkatan teknologi dibidang hardware maupun software membuat telepon seluler semakin beragam fungsinya. Telepon selular yang diklasifikasikan ke dalam area global yang ditinjau dari jarak antara transmitter dan receiver-nya, selain sebagai alat komunikasi juga mempunyai kegunaan mengirim pesan singkat (sms), pengingat waktu (reminder), kalender, kalkulator, radio, multimedia player yang dapat memproses file audio, video dan gambar. ${ }^{1}$

Meskipun produsen telepon seluler, lembaga regulator, dan penyedia layanan menjamin bahwa telepon seluler aman, namun perdebatan dan kontroversi secara global mengenai efek kesehatan dari telepon seluler terus berlanjut. Banyak kalangan mengklaim bahwa radiasi gelombang elektromagnetik yang dipancarkan dapat mengganggu kesehatan pengguna. Anggapan ini juga dibenarkan oleh para ahli bidang telekomunikasi, namun tidak sedikit pula bantahan-bantahan oleh beberapa pihak yang menyangkal sebaliknya.,

Para ahli mengungkapkan radiasi yang ditimbulkan telepon seluler tidak seratus persen bisa menyebabkan gangguan kesehatan terhadap manusia, mengingat masih banyak orang yang masih setia menggunakan piranti wireless ini untuk memudahkan aktifitas. Namun kekhawatiran dari masyarakat tetap muncul setelah mengetahui pancaran energi frekuensi radio (gelombang radio) dari telepon seluler berpotensi menyebabkan masalah kesehatan, dan kekhawatiran yang lain akan jumlah pengguna telepon seluler yang terus meningkat pesat. 3,4

Peningkatan besar dalam penggunaan telepon seluler di seluruh dunia per Juni 2009 terdapat lebih dari 4,3 miliar pengguna di seluruh dunia. ${ }^{5}$ Menurut laporan International Telecommunication Union (ITU) 2010 yang dikutip dari Institute for Policy Research Northwestern University, jumlah pengguna telepon seluler di Amerika Serikat bertambah dari 184,8 juta pada 2004 dan meningkat menjadi 298,4 juta pada tahun
2009. ${ }^{6}$ Data hasil Survei Sosial Ekonomi Nasional (SUSENAS) 2005 menunjukkan jumlah pengguna telepon seluler yaitu 0,114 juta rumah tangga dengan persentase $18,15 \%$ dari 0,629 juta rumah tangga di Sulawesi Utara. ${ }^{7}$

Telepon seluler harus memancarkan energi frekuensi radio pada tingkat yang cukup tinggi untuk mencapai BTS (menara antena). Karena gelombang radio (microwave) yang dipancarkan secara langsung ke kepala pengguna, menyebabkan keamanan teknologi ini diragukan. ${ }^{2}$ Menurut studi dari Schörnborn et al yang dikutip dari Romanian J. Biophys, menunjukkan bahwa kepala orang dewasa menyerap 80\% dari radiasi yang dipancarkan oleh telepon seluler. $^{8}$

Penelitian dari Oktay dan Dasdag yang dikutip dari Bahrain Medical Buletin, dan dipresentasikan pada Pertemuan Tahunan American Academy of Otolaryngology-Head and Neck Surgery, 100 orang yang telah menggunakan telepon seluler selama lebih dari setahun mengalami peningkatan derajat gangguan pendengaran selama rentang 12 bulan. Studi ini menemukan bahwa orang yang menggunakan telepon seluler lebih dari 60 menit sehari memiliki ambang pendengaran yang lebih buruk daripada mereka yang menggunakannya kurang dari itu, selain itu orang yang menggunakan telepon seluler selama lebih dari satu jam per hari merasa sulit untuk membedakan suara frekuensi tinggi (misalnya s, f, h, t, dan z) pada awal kata. ${ }^{9}$

\section{METODE PENELITIAN}

Penelitian ini menggunakan metode analitik observasional dengan cara potong lintang (cross sectional), dimana pengambilan data hanya dilakukan satu kali pada satu saat. Penelitian ini dilaksanakan pada bulan November-Desember 2012 di RSUP Prof. R. D. Kandou bagian THT-KL Malalayang Manado. Populasi dalam penelitian ini adalah semua mahasiswa angkatan 2009 Fakultas Kedokteran Universitas Sam Ratulangi Manado dengan sampel penelitian sebanyak 40 orang mahasiswa yang 
dipilih berdasarkan kriteria yang telah ditentukan. Kriteria inklusi dalam penelitian ini: bersedia untuk ikut serta dalam penelitin dan manandatangani informed consent, lama penggunaan telepon seluler lebih dari 10 menit dalam sehari dengan frekuensi menelepon lebih dari satu kali, dapat berkomunikasi dengan baik. Kriteria eksklusi yaiu mahasiswa yang memiliki gangguan pendengaran dan menderita sakit saat menjalani penelitian. Instrumen dan alat dalam penelitian yaitu lembar informed consent, lembar kuesioner penelitian, alat tulis menulis dan laptop yang memiliki aplikasi SPSS, lembar audiogram, audiometri (Screening “Audiometer QH10" Quadrant Instruments Australia 2008). Kalibrasi terakhir Agustus 2012, EFT.

\section{HASIL PENELITIAN}

Penelitian ini dilaksanakan selama satu bulan yakni pada pertengahan bulan November sampai pertengahan bulan Desember 2012, lokasi bertempat di RSU Prof. R. D. Kandou bagian THT-KL Malalayang Manado. Responden penelitian ini adalah mahasiswa angkatan 2009 Fakultas Kedokteran Universitas Sam Ratulangi Manado yang berjumlah 349 orang. Sebanyak 115 orang bersedia mengisi kuesioner dan yang memenuhi kriteria serta bersedia mengikuti penelitian sebanyak 40 orang yaitu laki-laki sebanyak 8 orang (20\%) dan perempuan sebanyak 32 orang (80\%).

Hasil penelitian menunjukkan sejumlah gambaran umum responden berupa jenis kelamin, usia, gangguan pendengaran pada telinga kiri dan telinga kanan, dan jenis telepon seluler. Dari Tabel 1 menunjukkan bahwa dari 40 responden (100\%) yang memenuhi kriteria penelitian terdapat responden berusia 19 tahun sebanyak 3 orang (7,5\%), 20 tahun sebanyak 13 orang (32,5\%), pada usia 21 tahun yaitu sebanyak 18 orang (45\%), dan 22 tahun sebanyak 6 orang (15\%).

Sebaran mahasiswa menurut gangguan pendengaran telinga kiri dapat dilihat pada Tabel 2. Setelah dilakukan pemeriksaan dengan menggunakan audiometri didapat- kan hasil bahwa dari 40 orang responden terdapat 8 orang (20\%) yang memiliki gangguan pendengaran ringan pada telinga kiri, sedangkan sisanya yaitu 32 orang (80\%) memiliki fungsi pendengaran yang masih dalam keadaan normal dan dapat dilhat di Tabel 2.

Tabel 1. Sebaran mahasiswa menurut usia (Tahun)

\begin{tabular}{ccc}
\hline Usia Responden & $\mathbf{n}$ & $\mathbf{\%}$ \\
\hline 19 & 3 & 7.5 \\
20 & 13 & 32.5 \\
21 & 18 & 45.0 \\
22 & 6 & 15 \\
\hline Total & 40 & 100.0 \\
\hline
\end{tabular}

Tabel 2. Sebaran mahasiswa menurut gangguan pendengaran pada telinga kiri

\begin{tabular}{ccc}
\hline $\begin{array}{c}\text { Gangguan } \\
\text { pendengaran pada } \\
\text { telinga kiri }\end{array}$ & $\mathbf{n}$ & $\mathbf{\%}$ \\
\hline Normal & 32 & 80.0 \\
Ringan & 8 & 20.0 \\
\hline Total & 40 & 100.0 \\
\hline
\end{tabular}

Pemeriksaan selanjutnya yaitu sebaran mahasiswa menurut gangguan pendengaran pada telinga kanan dapat dilihat pada Tabel 3 , masih dengan menggunakan audiometri didapatkan bahwa dari 3 orang responden (7.5\%) yang memiliki gangguan pendengaran ringan, sedangkan sisanya yaitu 37 orang (92.5\%) masih memiliki fungsi pendengaran yang normal.

Tabel 3. Sebaran mahasiswa menurut gangguan pendengaran pada telinga kanan

\begin{tabular}{ccc}
\hline $\begin{array}{c}\text { Gangguan } \\
\text { pendengaran pada } \\
\text { telinga kanan }\end{array}$ & $\mathbf{n}$ & $\mathbf{\%}$ \\
\hline Normal & 37 & 92.5 \\
Ringan & 3 & 7.5 \\
\hline Total & 40 & 100.0 \\
\hline
\end{tabular}

Tabel 4 menunjukkan bahwa jumlah responden yang menggunakan jenis telepon 
seluler terbanyak yaitu telepon seluler jenis BB sebanyak 23 (57.5), NO sebanyak 12 (30\%) dan SS sebanyak lima (12.5\%).

Tabel 4. Sebaran mahasiswa menurut jenis telepon seluler

\begin{tabular}{ccc}
\hline $\begin{array}{c}\text { Jenis Telepon } \\
\text { Seluler }\end{array}$ & n & \% \\
\hline BB & 23 & 57.5 \\
NO & 12 & 30.0 \\
SS & 5 & 12.5 \\
\hline Total & 40 & 100.0 \\
\hline
\end{tabular}

Berdasarkan hasil penelitian pada Tabel 5 yaitu nilai statistik audiogram telinga kiri dan kanan dari 40 orang mahasiswa didapatkan nilai minimum audiogram telinga kiri sebesar 15,90, nilai maksimum sebesar 30, untuk nilai mean sebesar 22,15, nilai median sebesar 22,50 dengan standar deviasi sebesar 3,64. Sedangkan untuk nilai audiogram telinga kanan didapatkan nilai minimum sebesar 14,70, nilai maksimum sebesar 26,70, untuk nilai mean sebesar 20,20, nilai median sebesar 20 dengan standar deviasi sebesar 3,24.

Tabel 5. Karakteristik nilai statistik audiogram telinga kiri dan kanan

\begin{tabular}{lcc}
\hline & $\begin{array}{c}\text { Audiogram } \\
\text { telinga kiri }\end{array}$ & $\begin{array}{c}\text { Audiogram } \\
\text { telinga kanan }\end{array}$ \\
\hline $\mathrm{N}$ & 40 & 40 \\
Minimum & 15,90 & 14,70 \\
Maximum & 30 & 26,70 \\
Mean & 22,15 & 20,20 \\
Median & 22,50 & 20 \\
SD & 3,64 & 3,24 \\
\hline
\end{tabular}

\section{BAHASAN}

Dari hasil penelitian analitik observasional, didapatkan bahwa 40 responden yang ikut serta dalam penelitian memiliki perbedaan fungsi pendengaran antara telinga kiri dan telinga kanan. Hasil pemeriksaan telinga kiri menunjukkan bahwa delapan orang (20\%) responden mengalami gangguan pendengaran ringan sedangkan 32 orang (80\%) lainnya memiliki fungsi pendengaran yang normal. Hasil pemeriksaan telinga kanan menunjukkan bahwa tiga orang $(7,5 \%)$ memiliki gangguan pendengaran ringan, sisanya 37 orang (92,5\%) memiliki fungsi pendengaran yang normal, serta keluhan telinga lain yang muncul yaitu tinitus sebanyak tujuh orang. Hasil ini memiliki persamaan dengan penelitian kasus kontrol yang dilakukan oleh Abduljawad $^{8}$, dimana ditemukan perbedaan antara hasil pemeriksaan fungsi pendengaran telinga kiri dan telinga kanan setelah menggunakan telepon seluler lebih dari satu tahun, tingkat paparan radiasi telpon seluler yang berbeda, serta timbulnya keluhan tinnitus. Gangguan pendengaran yang berbeda antara telinga kiri dan kanan tergantung pada tingkat paparan radiasi yang berbeda terhadap individu secara langsung. ${ }^{2}$ Dalam penelitian ini, sampel yang diteliti tidak memiliki penyakit atau keluhan telinga sebelumnya, namun keluhan tinnitus muncul setelah terpapar radiasi telepon seluler dalam jangka waktu yang cukup lama. Hasil yang sama juga didapatkan dari penelitian Karlidag, et al. ${ }^{10}$

Penurunan pendengaran ringan yang didapat dari hasil pemeriksaan audiometri pada beberapa responden umumnya disebabkan oleh induksi radiasi di koklea atau perubahan vaskular, namun mekanisme gangguan pendengaran masih belum terbukti. $^{11}$ Hal ini didukung oleh banyak penelitian yang dilakukan untuk mengevaluasi pengaruh radiasi elektromagnetik yang dipancarkan telepon seluler terhadap pendengaran orang dewasa bahwa tidak ada efek yang ditimbulkan. ${ }^{12}$

Hasil uji bivariat dengan Pearson correlation hubungan antara audiogram telinga kiri dengan radiasi telepon seluler diperoleh $\mathrm{r}=-0,256$ dengan $\mathrm{p}=0,056$, hasil ini menunjukkan secara statistik tidak bermakna pada kedua variabel $(\mathrm{p}=0,056>$ $\alpha=0,05)$. Sedangkan uji bivariat pada telinga kanan diperoleh $\mathrm{r}=0,210$ dengan $\mathrm{p}=$ 0,097, hasil ini juga menunjukkan secara statistik tidak bermakna pada kedua variabel $(p=0,097>\alpha=0,05)$. Berdasarkan hasil uji bivariat diatas, penelitian ini tidak 
mendukung hipotesis adanya hubungan radiasi gelombang elektromagnetik telepon seluler terhadap fungsi pendengaran. Hasil pengukuran radiasi telepon seluler yang dihubungkan dengan hasil pemeriksaan audiometri secara statistik tidak bermakna.

Hal lain yang mungkin mempengaruhi hasil penelitian ini diantaranya mengenai aktifitas penggunaan earphone sebelumnya, seperti mendengarkan musik dengan volume keras dari telepon seluler dengan menggunakan earphone atau perangkat audio lain. Hal ini dapat menimbulkan bising kronik yang dapat mengganggu fungsi pendengaran. Intensitas suara yang dihasilkan oleh earphone bisa mencapai 110 dB. Paparan suara berintensitas $110 \mathrm{~dB}$ selama 1 jam per hari dapat menurunkan fungsi pendengaran. Penurunan fungsi pendengaran dapat bersifat sementara. Hal ini didukung penelitian yang dilakukan oleh Rahadian, Prastowo, dan Haryono ${ }^{13}$ yang menunjukkan adanya perbaikan fungsi pendengaran setelah penggunaan earphone dikurangi atau dihentikan.

\section{SIMPULAN}

Pengukuran radiasi gelombang elektromagnetik rata-rata tertinggi pada telepon seluler jenis BB tipe A yaitu 3,08 $\mu \mathrm{T}$, sedangkan yang memiliki nilai radiasi gelombang elektromagnetik terendah didapati pada telepon seluler jenis BB tipe B yaitu $0,13 \mu \mathrm{T}$. Hasil pengukuran audiomeri telinga kiri didapatkan nilai gangguan ringan yaitu 29,17 dB, sedangkan pada hasil pengukuran audiometri telinga kanan nilai gangguan ringan pada telinga kanan yaitu 26,7 dB.

\section{UCAPAN TERIMA KASIH}

Penulis mengucapkan banyak terima kasih kepada dr. Jimmy F. Rumampuk, M.Kes, AIFO dan dr. Wenny Supit, MRepro, Sp.And atas segala saran dan perbaikan yang telah diberikan. Terima kasih juga disampaikan kepada semua pihak baik yang secara langsung maupun tidak langsung telah menumbuhkan ide atau gagasan dalam pemikiran penulis serta membantu penulis menyelesaikan penelitian dan artikel ini.

\section{DAFTAR PUSTAKA}

1. Seta RB, Wicaksana IW. Database address book pada handphone untuk platform series $40 \quad 5^{\text {th }}$ edition menggunakan record management system. 2012 Jun 1 (cited 2013 Jan 22). Available from: http://repository. gunadarma.ac.id/bitstream/123456789/29 91/1/Artikel_50404851.pdf.

2. Uddin AS, Ferdous J. Radiation exposure of cell phones \& its impact on human health - a case study in South Asia (Bangladesh) and some recommendations. Journal of Theoretical and Applied Information Technology. 2010;19:15-16.

3. Swarmadika IB. Pengaruh radiasi gelombang eletromagnetik Terhadap Kesehatan Manusia. Radiasi Elektro magnetik dari Telepon Seluler. 2009:8;108.

4. Anonymous. Cell phone and cancer risk. National Cancer and Institute. 2012. Available from:URL: http://www. cancer.gov/cancertopics/factsheet/Risk/ce llphones.

5. Rani B, Singh U, Maheshwari R. Cell phone radiation and health: an outlook. Bulletin of Environment, Pharmacology \& Life Sciences. 2011;1:3.

6. Institute for Policy Research Northwestern University. The prevalence of smartphone use among a wired group of young adults. 2010.

7. Badan Pusat Statistik. Profil pemanfaatan teknologi informasi oleh masyarakat. 2006 Aug 14 (cited 2012 Oct 19). Available from: URL: http://www.bps. go.id/brs_file/profilti-14agt06.pdf.

8. Khadrawy YA, Ahmed NA, Ezz HS, Radwan NM. Effect of electromagnetic radiation from mobile phone on the levels of cortical amino acid neurotransmitters in adult and young rats. Romanian J Biophys. 2009;19:1.

9. Al-Abduljawad KA. Effects of the mobile phones on the hearing function of the users. Bahrain Medical Buletin. 2008;30:3-4.

10. Karlidag T, Kaygusuz I, Kelas E, Yalcin S, Serhatlioglu SS, Acik Y, et al. Hearing in workers exposed to low-dose radiation for a long period. Elsevier. 2004;194:63. 
1052 Jurnal e-Biomedik (eBM), Volume 1, Nomor 2, Juli 2013, hlm. 1047-1052

11. Environtment \& Human Health, Inc. Cell phone. 2012.

12. Uzwali M, Nirmala L, Das A, Paudel BH, Mathur NN, Singh PN. Effects of electromagnetic waves emitted from mobile phone on auditory evoked potential in school children. Curr Pediatr Res. 2012;16:37.

13. Rahadian J, Prastowo NA, Haryono R. Pengaruh penggunaa earphone terhadap fungsi pendengaran remaja. Majalah Kedokteran Indonesia. 2010;60:469-72 